Original Paper http://ajol.info/index.php/ijbes http://indexmedicus.afro.who.int

\title{
Floristic diversity of Loranthaceae Family and their potential host species in Sudano-sahelian zone of Cameroon: case of Diamare plain in Far-North Region
}

\author{
Souare KONSALA ${ }^{1 *}$, Gilbert TODOU ${ }^{1}$, Froumsia MOKSIA ${ }^{1}$, Divine Tii MUNTING ${ }^{1}$, \\ Jeanne Flore NNANGA ${ }^{1}$, TCHOBSALA ${ }^{1}$ and Ibrahima ADAMOU ${ }^{2}$ \\ ${ }^{1}$ University of Maroua, Faculty of Science, Department of Biological Sciences, P.O. Box: 814 Maroua, \\ Cameroon. \\ ${ }^{2}$ University of Ngaoundéré, Faculty of Science, Department of Biological Sciences, P.O. Box: 454 Ngaoundéré, \\ Cameroon. \\ *Corresponding author; E-mail: ksouare07@gmail.com
}

\begin{abstract}
There is an increasing interest in parasitic plants and infectious disease community ecology in intertropical regions. The study examined the floristic diversity of Loranthaceae family and their potential host species in the ecoregion of Diamare plain in Cameroon. Reasoned sampling method was performed and experimental device consisted of 02 main treatments (Diamare and Mayo-Kani divisions), 08 secondary treatments (councils) and 32 replications (villages), with four (04) villages per council. We used itinerary botanical survey method of $1000 \mathrm{~m}$ x $20 \mathrm{~m}$ in each village, totalizing 64 ha and all parasitic plants and their potential hosts were inventoried. A total of 11645 ligneous individuals was inventoried in the Diamare division, distributed within 65 species, 44 genera, and 22 Families. In Mayo-Kani division, a total of 16645 ligneous individuals were inventoried, distributed in 58 species, 41 genera and 19 families. There was a significant difference between the two divisions in terms of individuals ( $p<0.001)$. In total, nine parasitic plants of the Loranthaceae family were inventoried, with five species identified at the level of species $(55.55 \%)$ and four species at the level of genera (44.44\%): Agelanthus dodoneifolius (DC.) Polh. and Wiens, Tapinanthus globiferus (A. Rich.) Van Tiegh., Tapinanthus oleifolus (JC. Wendl.) Danser; Tapinanthus voltensis Van Tiegh. ex Balle; Tapinanthus ophiodes (Sprague) Danser, Tapinanthus sp1., Tapinanthus sp2., Tapinanthus sp3. and Phragmanthera sp. Agelanthus dodoneifolius, Tapinanthus globiferus and T. ophiodes recorded a weak parasitic specificity (PSp $=81.39 \% ; 72.09 \%$ and $30.23 \%$ respectively). Combretaceae and Mimosaceae families showed the greatest number of sensitive host species to Loranthaceae infestation (20.89\% and $16.27 \%$ respectively). There was no significant difference between parasitic specificity of Loranthaceae and parasitic sensitivity of host species $(p>0.05)$, and both were positively correlated $(r=0.96)$. Efforts are required to control the development of Loranthaceae in sudano-sahelian zone especially in ecosystem plantations.
\end{abstract}

(C) 2020 International Formulae Group. All rights reserved.

Keywords: Floristic diversity, Loranthaceae, host species, Diamare plain, Cameroon

\section{INTRODUCTION}

Loranthaceae are locally and commonly called using the appellation "African mistletoe". They are phanerogams, hemiparasites, chlorophyllian and epiphytes which fix on aerian parts of their host (Koffi et al., 2014). These vascular parasites are responsible for varied economic, ecological, morphological and physiological damages on different cultures and ligneous vegetations 
(Sallé et al., 1998). They fix to their host using a specialized organ called haustorium, which establishes contact with the host at the level of the xylem conductive tissues (Boussim et al., 1993). These vascular parasites are present in all intertropical regions and in certain temperate zones and are sprawling to other regions. In the world, a total of 950 species and 77 genera belonging to this Family are known (Boussim et al., op. cit.).

In Africa, Polhill and Wiens (1998) identified more than 500 species of the Loranthaceae Family, and the investigations dealed mostly with crop protection. In Burkina-Faso, Boussim (2002) reported that large agroforestry surface areas parasitized by Loranthaceae led to massive tree deaths, most often in the absence of human control and intervention through diverse techniques of fight. In Ivory Coast, Soro et al. (2006) have raised an alert on the negligence of Loranthaceae Family that has now become a veritable nightmare in both natural vegetation and plantations alike. These vascular plants in the form of small shrubs develop on the trunk of their hosts. The growth of the host is thus slowed down and often ends up with death. In Cameroon, Ballé (1982) inventoried twenty six (26) species regrouped into seven (07) genera. Plantations and natural occurring woody species are main parasitic grounds of Loranthaceae. Many countries by experience have testified that Loranthaceae are responsible for decrease of productivity especially in agroforestry plantations. These parasitic species which have not been sufficiently studied and vulgarized by research foundations constitute a real threat to trees in home gardens (Dibong et al., 2008). In East Cameroon, Theobroma cacao, Coffea robusta, Dacryodes edulis plantations and coastal gardens along roads created by forest exploitation are major Loranthaceae targets (Dibong et al., 2012; Azo'o et al., 2013).

The Diamare plain in the sudanosahelian ecoregion of Cameroon is facing the challenges such as overexploitation and degradation of plant resources, desertification and global warming. Being aware that Loranthaceae are parasites and capable of accelerating plant resources degradation which are already threatened in this zone, there was a great necessity of carrying out a reconnaissance survey of these hemiparasites in order to take appropriate conservation measures to preserve its diversity and regulate its growth in the study area. The survey aimed at contributing to the knowledge of Loranthaceae diversity and their potential hosts in the Sudano-sahelian zone of Cameroon in a view to fighting against degradation of resource plants.

\section{MATERIALS AND METHODS \\ Study site}

The study was carried out in the FarNorth Region of Cameroon, in the Diamare plain including Mayo-Kani and Diamare divisions. These divisions cover a total area of $6450 \mathrm{~km}^{2}$ and a population of 768603 inhabitants (MINATD, 2010). It is located between $10^{\circ} 0^{\prime} \mathrm{N}$ to $10^{\circ} 48^{\prime} \mathrm{N}$ and $14^{\circ} 0^{\prime} \mathrm{E}$ to $14^{\circ} 48^{\prime}$ E (Figure 1). The climate is of the Sudano-sahelian zone and is characterized by two seasons, a long dry season (8 to 9 months) spanning from October to May and a short rainy season (3 to 4 months) from June to September (Fotsing, 2009). Very high temperatures reaching $45{ }^{\circ} \mathrm{C}$ under shade and a very dry atmosphere are experienced from March to June. Rainfall varies between 600 and $900 \mathrm{~mm} /$ year, with maximum rainfall mostly between July and August (Djibrilla, 2016). Hydrography is made up of temporal flowing rivers (Mayos) which dry up at the end of the rainy season. The main soil types encountered are vertisols, hardés, sandy soils, rocky soils in mountain areas, and silty soils favorable to market gardening (FAO, 2011).

The vegetation is characterized by a shrub steppe of the Sudano-sahelian type. The most important plant species are: Adansonia digitata, Guiera senegalensis, Tamarindus indica, Acacia albida, Acacia spp., Ziziphus mauritiana and Ficus spp. Most of these plants are used for livestock feed (Wafo, 2008). Other African mistletoe and Acacia albida are appreciated for their leaves serving as fodders and their fertilizing roots. The wildlife is poor and is endangered due to the lack of a conducive environment for their development. Some species are mostly located in the 
mountains, and include rodents (mice, rats, damans, squirrels, hares), reptiles (lambs, lizards, snakes), locusts and caterpillars, sparrows; hyenas; panthers and wild cats; monkeys (IPCC, 2007). Most of the people rely on agriculture, livestock and forest resources to meet their basic needs.

\section{Data collection \\ Inventory of potential host species and parasitic plants}

The two divisions, Diamare and MayoKani, constituted the basis of the study (main treatments). In each division, four (04) councils were sampled constituting the secondary treatments and four (04) villages (replications) in each council. We used reasoned sampling method developed by Grangé and Lebart (1992) for the selection of the councils, considering the presence of ligneous plant formations with individuals harboring Loranthaceae species. We also used the itinerant botanical survey method (Amon, 2006; Soro, 2010) for the floristic inventories. As such, four (04) itineraries of $1000 \mathrm{~m} \times 20 \mathrm{~m}$ constituting the replications were made in each council, making a total of 64 ha throughout 32 itineraries (Figure 2) in different plant formations, namely gardens, reforested sites, natural sites, spontaneous trees and shrubs which are likely to be parasitized by Lorantahaceae. To avoid or reduce the homogeneity of host species that could bias the results of this research, each itinerary was realized at least $2 \mathrm{~km}$ away from the other.

Along the itinerary, all the woody potential host species and the parasitic plants were inventoried. For each host species, parameters such as the presence or absence of Loranthaceae species were recorded and the names of the host species and the Loranthaceae species were given on the basis of an identification key (Boussim, 2002). Also, the position of parasite on the host and the number of parasitic tufts were recorded. For each new parasite and woody host that identification on the field is not certain, a sample is collected by means of an inventory knife, or direct hand harvest. In cases of tall hosts, an inventory assistant climbs up the host and harvest the Loranthaceae for the constitution of herbarium. He equally observes properly, takes photos to permit the group to identify the species. Notwithstanding, some hosts are inaccessible and Loranthaceae species found on them were observed by means of a telescope that draws the parasite closer for proper observation.

Assessment of parasitic specificity of Loranthaceae species and parasitic sensitivity of host species

It is often stated that a good parasite does not kill its host. That said, variation in the degree of pathogenicity exhibited by various parasitic plants is great, from those which exert little impact on their hosts to those which dramatically affect the host physiology and fecundity. Pathogenicity depends upon many factors, such as the biomass ratio of parasite to host, the number of parasites attached to an individual host plant, the length of time required for the parasite to complete its life cycle, and possibly the degree of coevolutionary "tuning" that has occurred over time between the two species. All individuals of woody species which are parasitized and non parasitized were recorded and parasitic plants and number of tufts on all trees were counted. We measured the parasitic sensitivity which refers to the number of parasitic plants per host, and the parasitic specificity which refers to the number of hosts affected by the parasitic plants with respect to the total number of hosts (Houenon et al., 2012).

\section{Data processing and analysis}

We assessed diversity of potential host species with Shannon-Weaver diversity index $\left(\mathrm{H}^{\prime}\right)$ (Magurran, 2004) and Shannon's Evenness index (EQ). Diversity index takes into account not only the number of species but also whether species are more or less equally abundant, or whether in contrast one or a few species dominate.

$\mathrm{H}^{\prime}=-\Sigma \mathrm{Ni} / \mathrm{N} \log _{2} \mathrm{Ni} / \mathrm{N}$, where $\mathrm{H}^{\prime}=$ index of species diversity (bits), $\mathrm{Ni}=$ number of individuals of a given species $\mathrm{i}, \mathrm{N}=$ total number of individuals, $\log _{2}=\operatorname{logarithm}$ in basis 2 .

$\mathrm{EQ}=\mathrm{H}^{\prime} / \log _{2} \mathrm{~N}$, this index varies from 0 to 1 .

To describe the ecological importance of host families within each itinerary as well as for the total flora, the family importance value index (FIV) (Mori et al., 1983), was also calculated: 
FIV = family relative diversity + relative density + relative dominance

Family relative diversity $=$ (number of species in a family/total number of species) $\times 100$

Relative density $=$ (number of trees of the species or family/total number of trees) $\times 100$

Relative dominance $=$ (basal area of $a$ species/basal area of all the species) x 100

The parasitic species were identified on the field and confirmed by other authors' surveys (Dibong et al., 2008; Soro et al., 2010; Dibong et al., 2012; Azo'o et al., 2013; Koffi et al., 2014).

The rate of parasitic specificity (PSp) of the Loranthaceae species was determined using the following formula (Hoffmann, 1994):

PSp $=\frac{\text { NHSIPP }}{\text { TNHS }}$ X 100

PSp : parasitic specificity ;

NHSIPP : Number of host species infested by a parasitic plant;

TNHS : Total number oof host species.
Parasitic sensitivity (PSe) was appreciated for each host plant according to the number of parasitic plants/host: little sensitive host (1 to 2 parasitic plants); sensitive host (3 to 4 parasitic plants); high sensitive host (5 to 6 parasitic plants); very high sensitive host ( $\geq 7$ parasitic plants) (Houenon et al., 2012).

\section{Statistical analysis}

Analysis of variance (ANOVA) was used to compare the host vegetation abundance between the two divisions of the Diamare plain. Student test (t. test) was conducted in order to know if differences between parasitic specificity of Loranthaceae species and parasitic sensitivity of host species were statistically significant. The relationships between parasitic specificity and parasitic sensitivity were investigated using correlation analysis (Pearson).

All the statistical analyses were performed at the level of 0.05 with Origin 6.0 and Xlstat Softwares

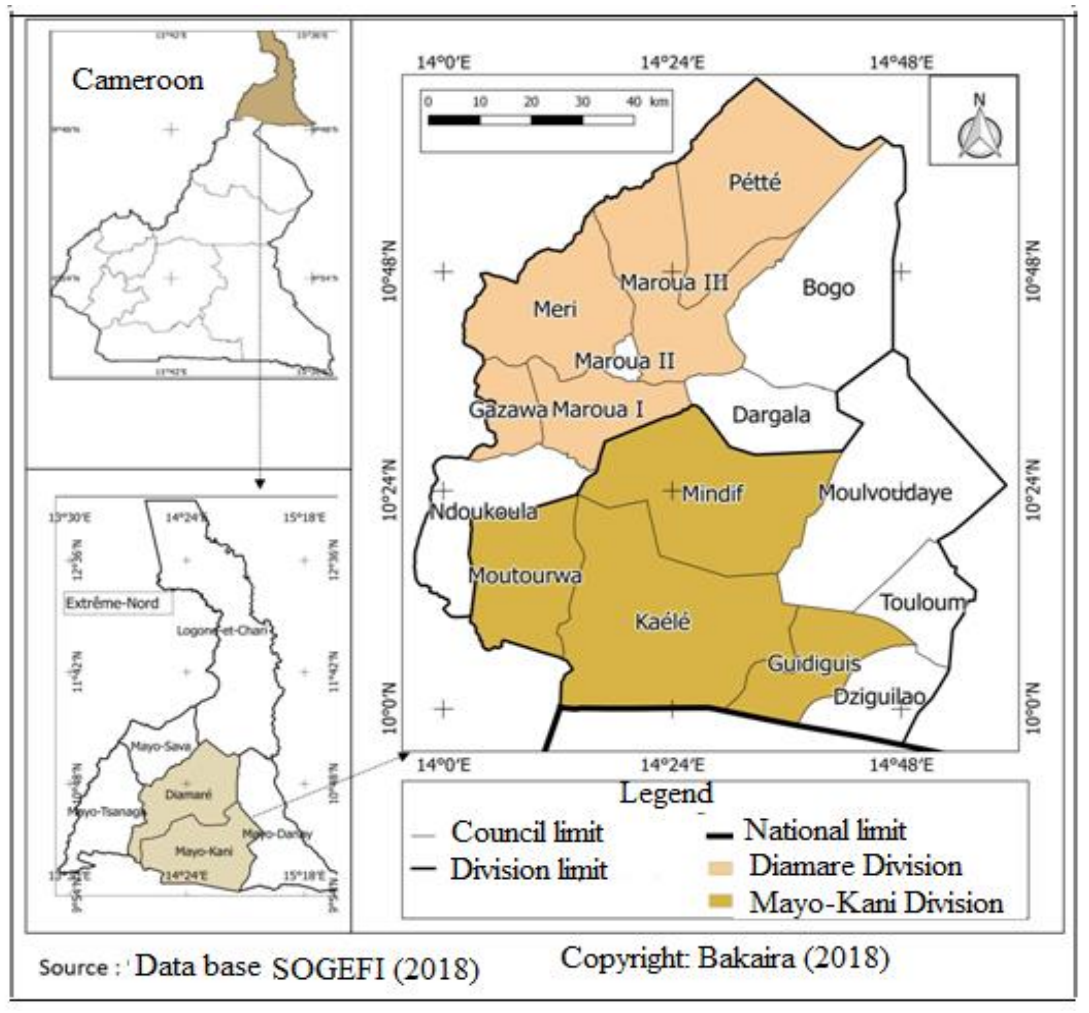

Figure 1: Map of location of the study site. 


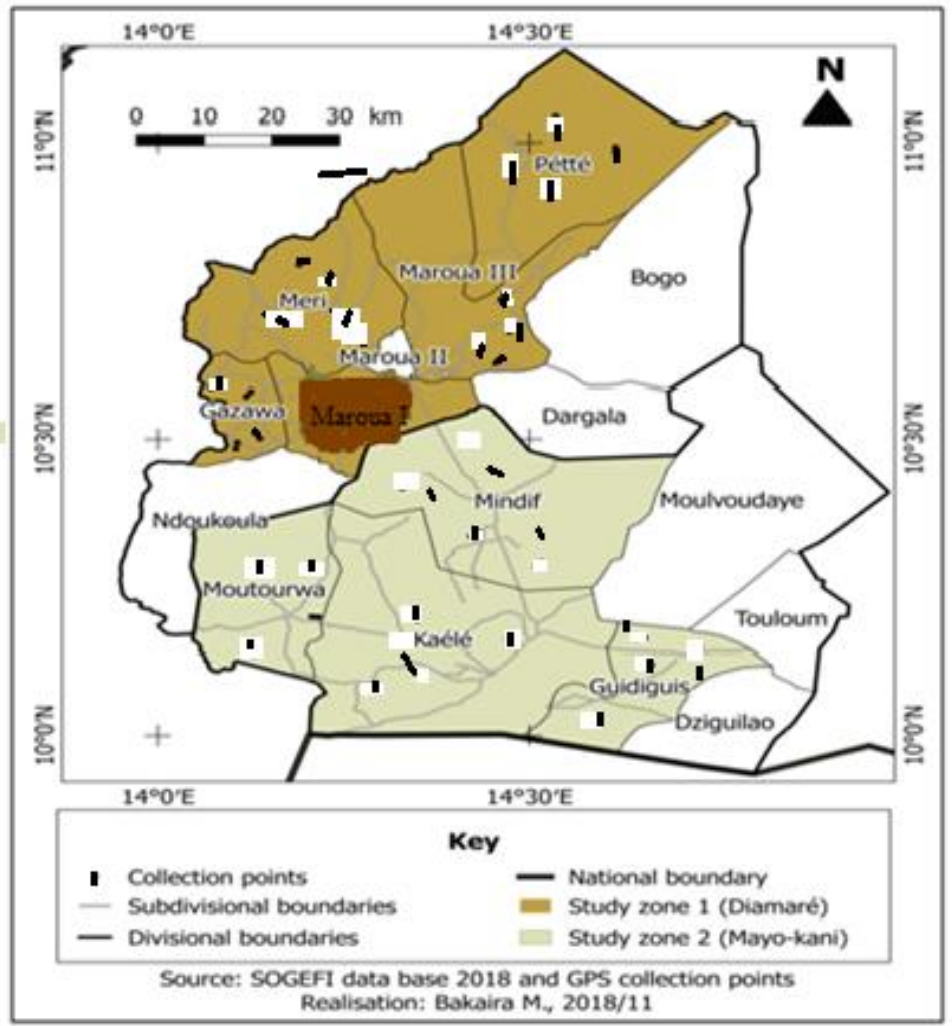

Figure 2: Map of study site showing the different points of data collection.

\section{RESULTS}

\section{Floristic diversity and composition of potential host species in Diamare plain}

A total of 11645 ligneous individuals was inventoried in the Diamare division which are distributed in 65 species, 44 genera, and 22 Families. In Mayo-Kani division, a total of 16 645 individuals were inventoried and distributed in 58 species, 41 genera and 19 Families. Diamare division was then more diversified than Mayo-Kani division with 65 species and 58 species respectively. However, there was a very significant difference between the two sites in terms of individuals (ANOVA, $\mathrm{p}<0.001)$. The Shannon diversity value in Diamare division was moderate $\left(\mathrm{H}^{\prime}=3.44\right.$ bits) and weak in the Mayo-Kani division $\left(\mathrm{H}^{\prime}\right.$ $=2.91$ bits). The Shannon's Evenness index values were 0.49 and 0.34 respectively (Table 1). In Mayo-kani division, most of the individuals were concentrated on a species, Azadirachta indica which is largely extended in that zone.

The five (05) most importance families (those of the highest values of FIV index) accounted for $66.17 \%$ of the total FIV. They contributed $46.75 \%$ of the total number of potential host species of all the botanical surveys. The five families with the highest number of individuals and basal area were Mimosacaea (FIV = 58.79); Meliaceae (FIV = 49.41); Combretaceae (FIV = 31.53); Anacardiaceae (FIV $=28.18$ ); Balanitaceae (FIV $=27.90)$. The most species-rich families were Mimosaceae (14 species); Combretaceae (11 species) and Anacardiaceae (08 species). A large group of families were represented by only one species. They were Balanitaceae, Sterculiaceae, Ebenaceae, Bombacaceae, Asclepiadaceae, Capparaceae, Celastraceae, Moringaceae, Loganiaceae, Verbenaceae, Sapotaceae, Bignoniaceae, Olacaceae and Rhamnaceae (Table 2).

\section{Taxonomic diversity of Loranthaceae species in Diamare plain}

A total of nine (09) Loranthaceae species was inventoried in Diamare plain. Five (05) of them were identified at the level of 
species, representing $55.55 \%$ of the total, including Agelanthus dodoneifolius (DC.) Polh. \& Wiens, Tapinanthus globiferus Blume, T. oleifolius (J.C.Wendl.), T. ophiodes (Sprague) Danser and T. voltensis Van Tiegh. ex Balle. The four (04) other species were determined at the level of genus, namely Phragmanthera sp., Tapinanthus sp1., Tapinanthus sp2. and Tapinanthus sp3. (Figure $3)$.

On the whole Diamare plain, three (03) genera were determined, notably Agelanthus Van Tiegh., Phragmanthera Van Tiegh. and Tapinanthus Blume. The genera of Agelanthus and Phragmanthera have one (01) species each and Tapinanthus recorded the highest number of species, that's seven (07) species. The absolute abundance varied from one species to another, A. dodoneifolius recorded the highest number of individuals (18 577) followed by $T$. globiferus (4 200 individuals) and T. ophiodes (214 individuals). The three species represented $99.86 \%$ of the total inventoried individuals in terms of relative abundance. The least abundance $(\mathrm{n} \leq 5)$ was recorded by $T$. voltensis (03), Tapinanthus sp1. (05), Tapinanthus sp2. (02) and Tapinanthus sp3. (02) (Table 3). Tapinanthus voltensis, Phragmanthera sp., Tapinanthus sp1., Tapinanthus sp2. and Tapinanthus sp3. were only distributed in Mayo-Kani division.

\section{Parasitic specificity of Loranthaceae species and parasitic sensitivity of host species}

Amongst the 77 potential host species censused, 43 species were infested by Loranthaceae species, representing 55.84\%, with 38 native species and 5 exotic species (Azadirachta indica, Khaya senegalensis, Senna siamea, Moringa oleifera and Citrus limon). Agelanthus dodoneifolius and Tapinanthus globiferus were very often in association on the same hosts. Regarding the parasitic specificity, three groups of parasitic plants were distinguished: weak parasitic specificity, average parasitic specificity and high parasitic specificity. The species with weak parasitic specificity were: $A$. dodoneifolius $(\mathrm{PSp}=81.39 \%)$, T. globiferus $(\mathrm{PSp}=72.09 \%)$ and $T$. ophiodes $(\mathrm{PSp}=$ $30.23 \%)$. Tapinanthus oleifolius, Tapinanthus sp2 and Tapinanthus sp3 performed average parasitic specificity $(\mathrm{PSp}=4.65 \%)$. Three species, namely Phragmanthera sp., Tapinanthus voltensis and Tapinanthus $\mathrm{sp} 1$ realized high parasitic specificity $(\mathrm{PSp}=$ $2.32 \%$ ).

Amongst the 43 host species, three (03) classes were distinguished according to their parasitic sensitivity: class I (little sensitive) with 29 species, representing $67.44 \%$; class II (sensitive) with 12 species, that's 27.90\%; class III (high sensitive) with 02 species (Acacia senegal and Anogeissus leiocarpus), representing $4.65 \%$ of the whole infested species. The family of Combretaceae recorded the highest percentage of host species $(20.93 \%)$ followed by Mimosaceae (16.27\%), and contributed about $97.81 \%$ to the biplots (axes F1 and F2) showed by principal component analysis (PCA) (Figure 4). These two families represent the most important ones in terms of family important value (FIV) in the study zone.

The independent test ( $t$. test) showed no significant difference between parasitic specificity of Loranthaceae and parasitic sensitivity of host species (t. test, $\mathrm{ddl}=38 ; \mathrm{p}=$ $0.702 ; \alpha=0.05$ ). Both, parasitic specificity and parasitic sensitivity, were high positively correlated (Pearson, $r=0.96 ; \alpha=0.05$ ). The more sensitive a species, the more it's infested by several parasitic plants (Figure 5).

A total of thirty four (34) species representing $44.15 \%$ were not infested by Loranthaceae, namely Acacia polyacantha, A. sieberiana, Albizia zygia, Entada africana, Mimosa pigra, Dichrostachys cinerea, Prosopis africana, Anacardium occidentale, Lannea acida, L. humilis, L. schimperi, Mangifera indica, Annona senegalensis, Combretum aculeatum, Guiera senegalensis, Commiphora africana, C. kerstingii, Citrus grandis, Crateva adansonii, Feretia apondanthera, Mitragyna inermis, Gardenia aqualla, Euphorbia sudanica, Ficus asperifolia, $\quad F$. sycomorus, Maytenus senegalensis, Delonix regia, Eucalyptus camaldulensis, Pterocarpus erinaceus, $P$. lucens, Sterculia setigera, Stereospermum kunthianum, Strychnos spinosa and Ximenia americana (Table 4). 
Table 1: Number of taxa and diversity indices of woody species in the two divisions of Diamare plain.

\begin{tabular}{llll}
\hline Taxa and diversity indices & Diamare division & Mayo-Kani division & Total \\
\hline Number of individuals & 11645 & 16645 & 28290 \\
Number of Species & 65 & 58 & 77 \\
Number of Genera & 44 & 41 & 53 \\
Number of Families & 22 & 19 & 27 \\
Shannon index (bits) & 3.44 & 2.91 & 3.05 \\
Shannon's Evenness index & 0.49 & 0.34 & 0.40 \\
\hline
\end{tabular}

Table 2: Family importance value (FIV) of the five (05) most important potential host families of Loranthaceae in Diamare plain.

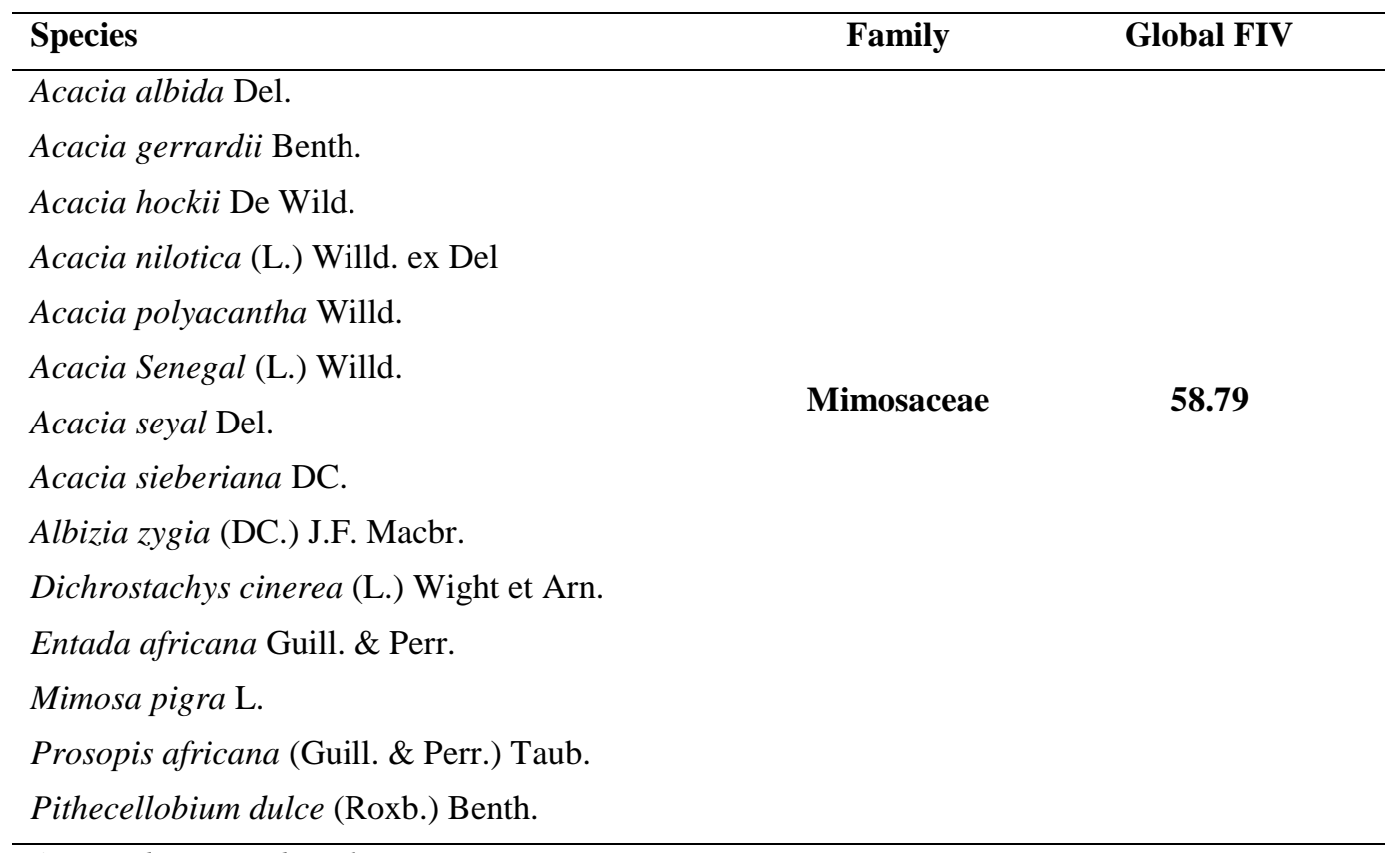

Anacardium occidentale $\mathrm{L}$.

Haematostaphis barteri Hook $\mathrm{f}$.

Lannea acida A. Rich.s.l.

Lannea fruticosa (Hochst. ex A. Rich.) Engl.

Lannea humilis (Oliv.) Engl.

Lannea schimperi (Hochst. ex A. Rich.) Engl.

Mangifera indica $\mathrm{L}$. 
Sclerocarya birrea (A. Rich.) Hochst.

Annona senegalensis Pers.

Hexalobus monopetalus (A. Rich.) Engl. \& Diels

Annonaceae

Anogeissus leiocarpus (DC.) Guill. \& Perr.

Combretum aculeatum Vent.

Combretum collinum Fresen

Combretum fragrans F. Hoffm.

Combretum glutinosum Perr. Ex DC.

Combretum molle R. Br. ex G. Don

Combretaceae

31.53

Terminalia glaucescens Hochst.

Terminalia laxiflora Engl.

Terminalia macroptera Guill. \& Perr.

Terminalia mantaly $\mathrm{H}$. Perr.

Guiera senegalensis J.F. Gmel.

Azadirachta indica A. Juss.

Khaya senegalensis (Desr.) A. Juss.

Meliaceae

49.41

\begin{tabular}{lll}
\hline Balanites aegyptiaca $(\mathrm{L}$.$) Del.$ & Balanitaceae & $\mathbf{2 7 . 9 0}$ \\
\hline Bombax costatum L. & Bombacaceae & 2.0 \\
\hline $\begin{array}{l}\text { Boswellia dalzielii Hutch. } \\
\text { Commiphora africana (A. Rich.) Engl. }\end{array}$ & Burseraceae & 3.15 \\
Commiphora kerstingii Engl. & &
\end{tabular}

Bridelia scleroneura Müll. Arg.

Euphorbia sudanica A. Chev.

Euphorbiaceae

3.0

Grewia bicolor Juss.

\begin{tabular}{|c|c|c|}
\hline Calotropis procera (Ait.) Ait. f. & Asclepiadaceae & 5.19 \\
\hline \multicolumn{3}{|l|}{ Citrus limon (L.) Burm. F. } \\
\hline Citrus grandis (L.) Osbeck & Rutaceae & 7.36 \\
\hline Crateva adansonii DC. & Capparaceae & 4.0 \\
\hline Diospyros mespiliformis Hochst. ex A. Rich. & Ebenaceae & 8.34 \\
\hline \multicolumn{3}{|l|}{ Feretia apodanthera Del. } \\
\hline Mitragyna inermis (Willd.) Kuntze & Rubiaceae & 12.23 \\
\hline \multicolumn{3}{|l|}{ Gardenia aqualla Stapf. \& Hutch. } \\
\hline \multicolumn{3}{|l|}{ Ficus asperifolia Miq. } \\
\hline \multicolumn{3}{|l|}{ Ficus glumosa Del. } \\
\hline \multicolumn{3}{|l|}{ Ficus sycomorus (Miq.) C.C. Berg } \\
\hline \multicolumn{3}{|l|}{ Ficus thonningii Blume } \\
\hline Maytenus senegalensis (Lam.) Exell. & Celastraceae & 3.0 \\
\hline Moringa oleifera L. & Moringaceae & 7.2 \\
\hline
\end{tabular}

Piliostigma reticulatum (DC.) Hochst. 
Piliostigma thonningii (Schum.) Milne-Redh.

Senna siamea Lam.

Senna singueana (Del.) Lock

Tamarindus indica $\mathrm{L}$.

Delonix regia (Boj.) Raf.

Psidium guajava $\mathrm{L}$.

Eucalyptus camadulensis F. Muel.

Myrtaceae

5.56

Pterocarpus erinaceus Poir.

Pterocarpus lucens Guill. \& Perr.

Fabaceae

3.70

Dalbergia melanoxylon Guill. \& Perr.

\begin{tabular}{lcl}
\hline Sterculia setigera Del. & Sterculiaceae & 1.01 \\
\hline Stereospermum kunthianum Cham. & Bignoniaceae & 1.03 \\
\hline Strychnos spinosa Lam. & Loganiaceae & 1.07 \\
\hline Vitellaria paradoxa Gaertn. f. & Sapotaceae & 1.25 \\
\hline Vitex doniana Sweet. & Verbenaceae & 1.04 \\
\hline Ximenia americana L. & Olacaceae & 1.01 \\
\hline Ziziphus mauritiana Lam. & Rhamnaceae & 2.99
\end{tabular}
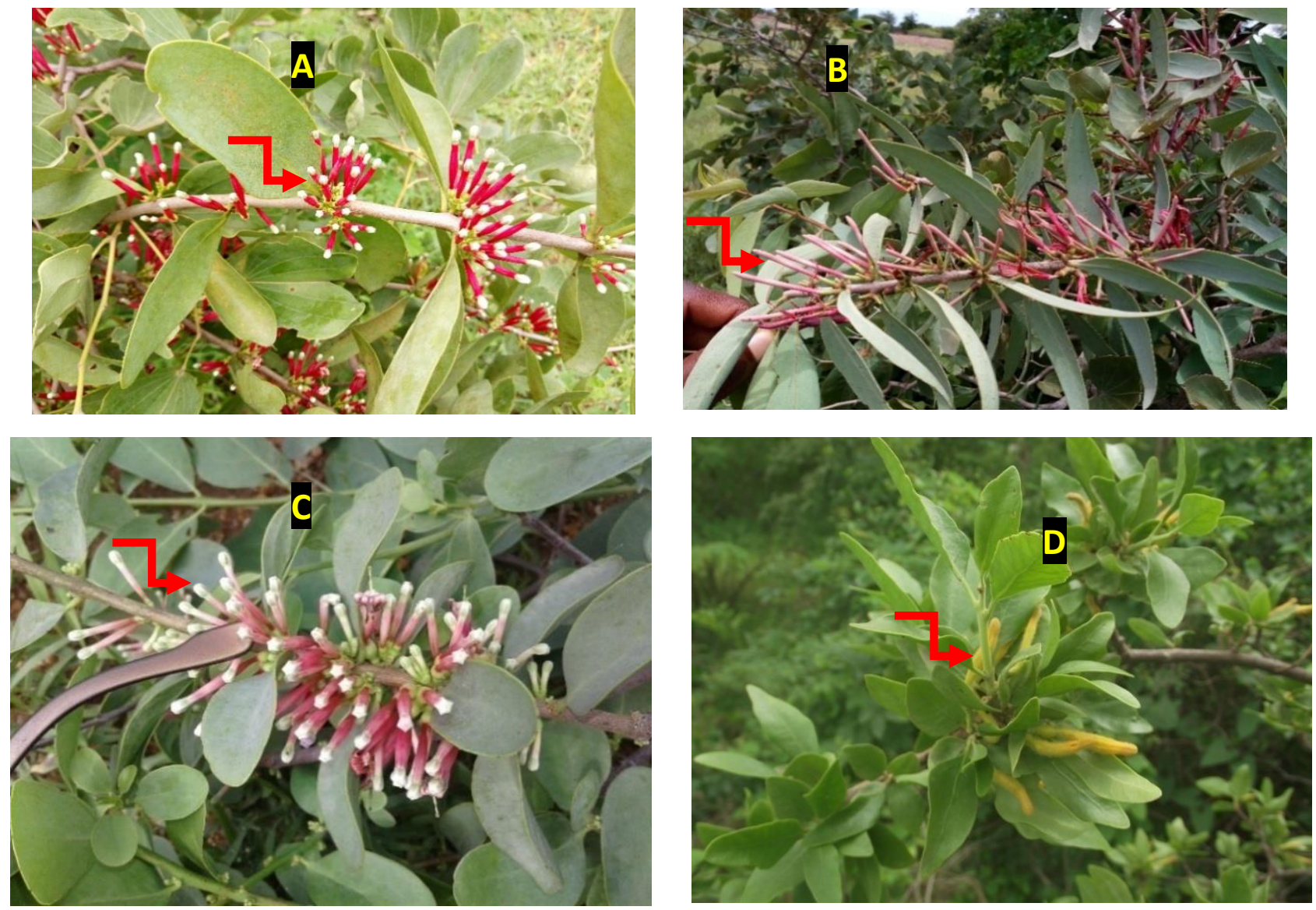

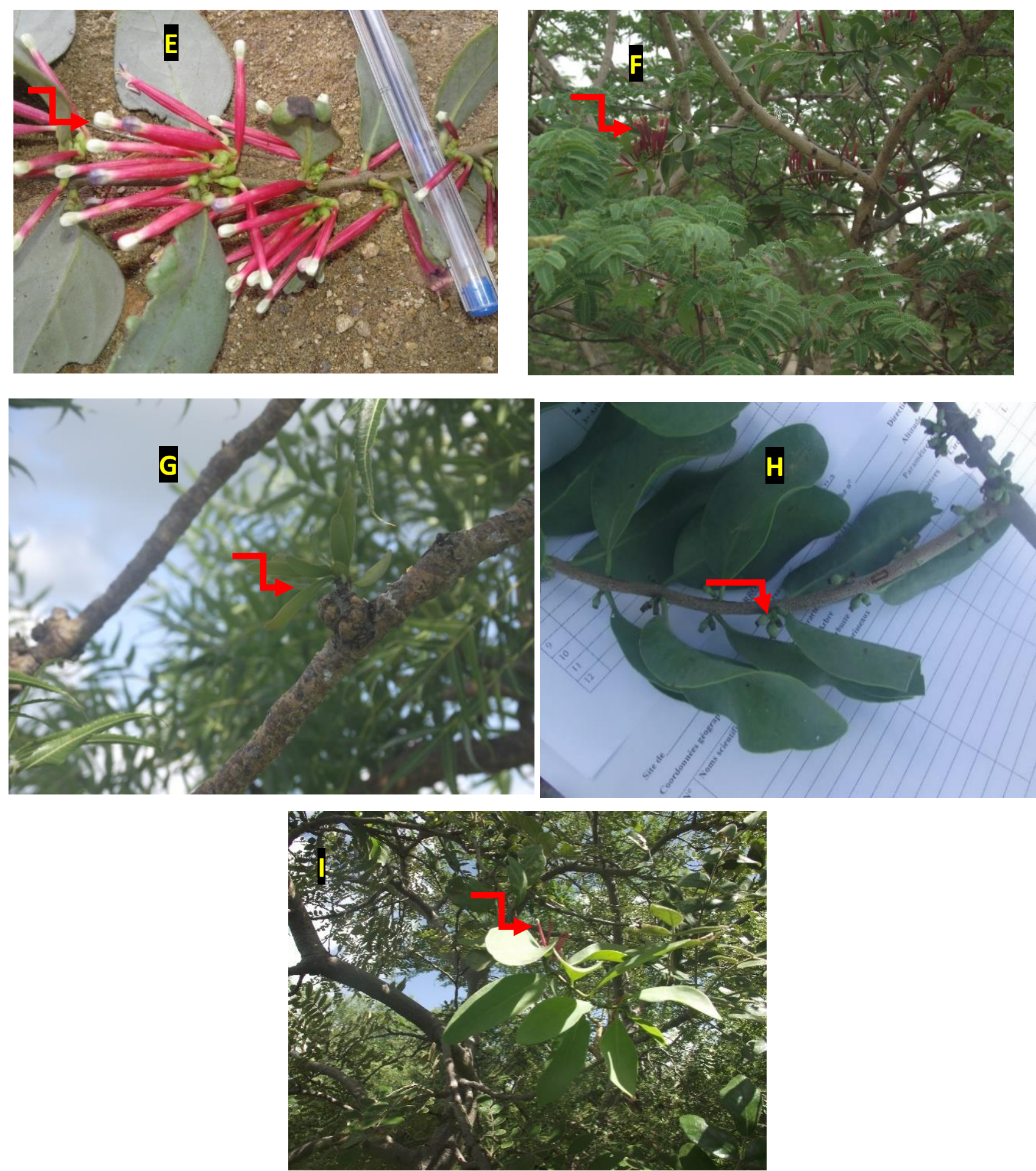

Figure 3: Loranthaceae species inventoried in Diamare plain.

A: Flowering branch of Tapinanthus globiferus $\quad$ B: Flowering branch of Agelanthus dodoneifolius $\quad$ C : Flowering branch of T. ophiodes $\quad$ D : T. voltensis on Acacia senegal $\quad$ E : Flowering branch of T. oleifolius $\quad \mathrm{F}$ : Flowering branch of Phragmanthera sp. G: Tapinanthus sp1. on Boswellia dalzielii $\quad$ H: Fruiting branch of Tapinanthus sp2. I: Tapinanthus sp3. on Lannea fruticosa. 
Table 3: Taxonomic diversity of Loranthaceae species and their abundance on host species.

\begin{tabular}{lllll}
\hline Family & Genera & Species & Absolute abundance & Relative abundance (\%) \\
\hline \multirow{5}{*}{ Loranthaceae } & Agelanthus & Agelanthus dodoneifolius & 18577 & 80.68 \\
\cline { 2 - 5 } & Phragmanthera & Phragmanthera sp. & 10 & 0.043 \\
\cline { 2 - 5 } & & Tapinanthus globiferus & 4200 & 18.24 \\
& Tapinanthus & Tapinanthus ophiodes & 214 & 0.92 \\
& & Tapinanthus oleifolius & 10 & 0.043 \\
& & Tapinanthus voltensis & 3 & 0.0001 \\
& & Tapinanthus sp1. & 5 & 0.0002 \\
& & Tapinanthus sp2. & 2 & 0.00008 \\
& & Tapinanthus sp3. & 2 & 0.00008 \\
\hline Total & 09 & 23023 & 99.93
\end{tabular}

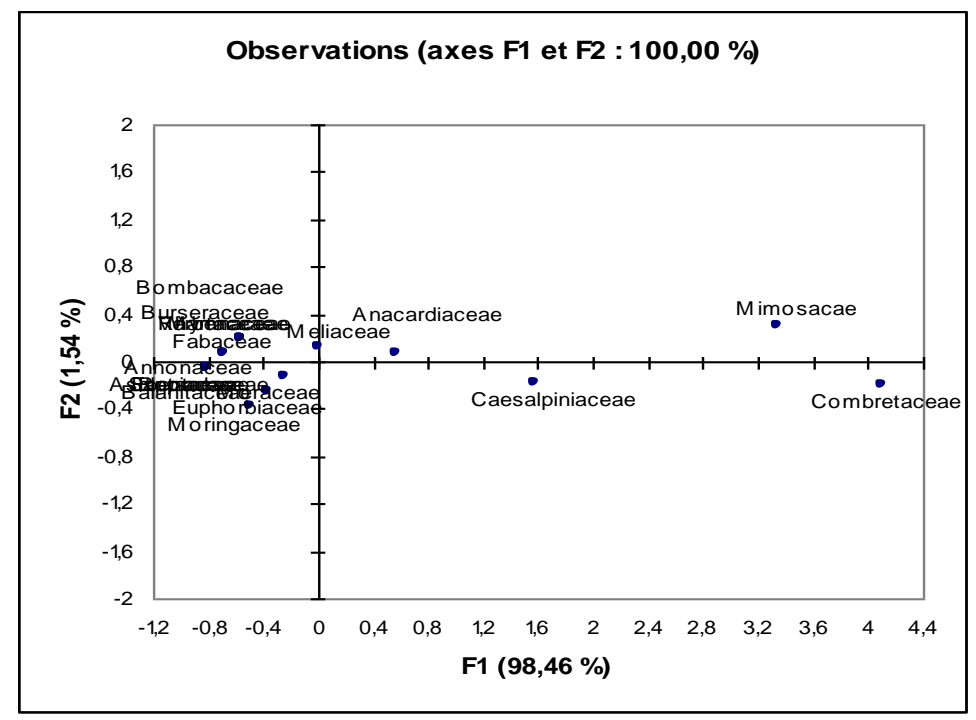

Figure 4. Similarity of host families according to their parasitic sensitivity showed by principal component analysis (PCA).

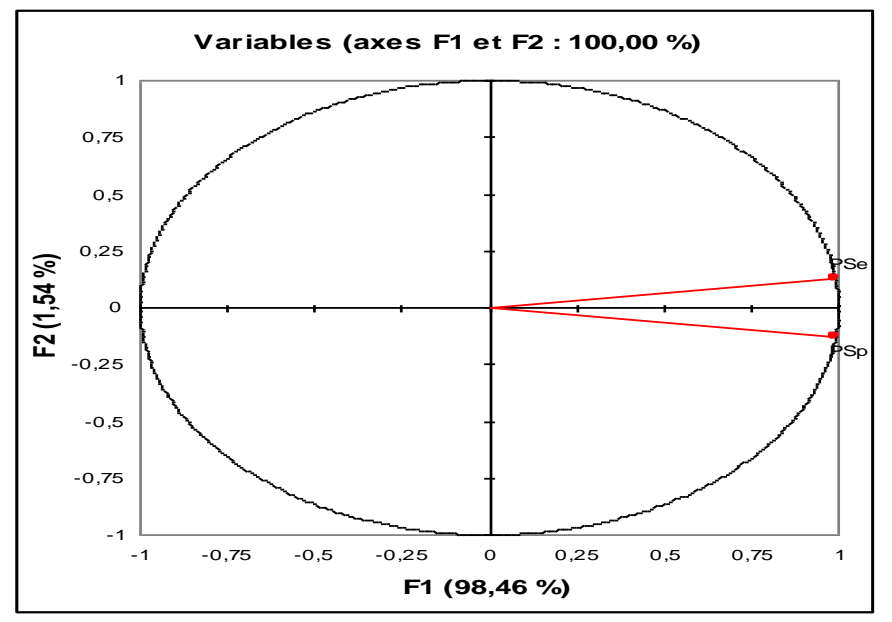

Figure 5: Correlation between PSe and PSp showed by PCA.

PSe : Parasitic sensitivity PSp : Parasitic specificity PCA : Principal component analysis 
S. KONSALA et al. / Int. J. Biol. Chem. Sci. 14(3): 896-915, 2020

Table 4 : Specificity of Loranthaceae species and sensitivity of host species.

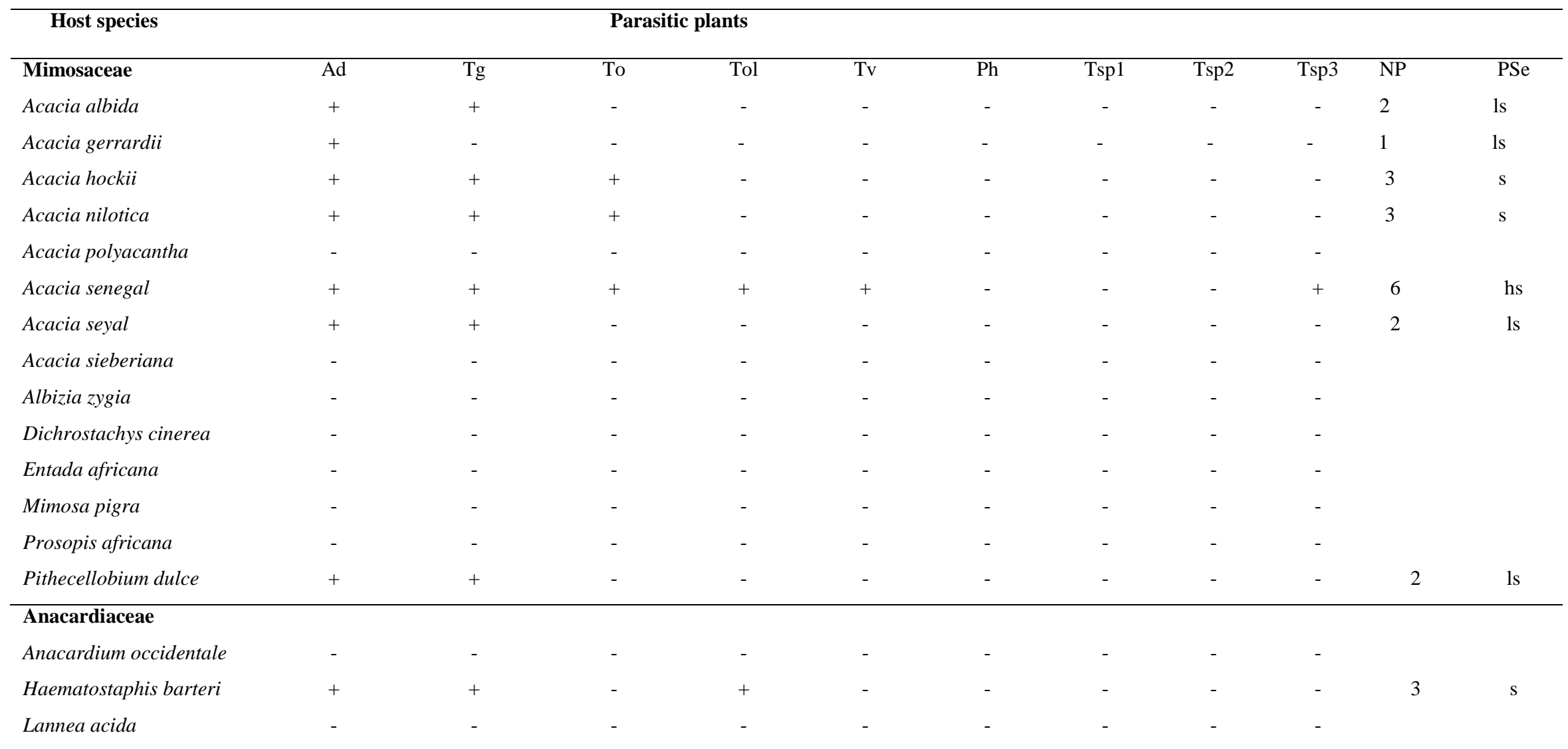


Lannea humilis

8.18

Lannea schimperi

Mangifera indica

Sclerocarya birrea

\begin{tabular}{|c|c|c|}
\hline 8.18 & - & - \\
\hline & - & - \\
\hline- & - & - \\
\hline 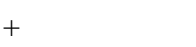 & + & - \\
\hline
\end{tabular}

\section{Annonaceae}

Annona senegalensis

Hexalobus monopetalus

\section{Combretaceae}

Combretum aculeatum

Combretum collinum

Combretum fragrans

Combretum glutinosum

Combretum molle

Terminalia glaucescens

Terminalia laxiflora

Terminalia macroptera

Terminalia mantaly

Anogeissus leiocarpus

Guiera senegalensis 
S. KONSALA et al. / Int. J. Biol. Chem. Sci. 14(3): 896-915, 2020

\begin{tabular}{|c|c|c|c|c|c|c|c|c|c|c|c|}
\hline \multicolumn{12}{|l|}{ Meliaceae } \\
\hline Azadirachta indica & + & + & + & - & - & - & - & - & - & 3 & $\mathrm{~s}$ \\
\hline Khaya senegalensis & + & + & - & - & - & - & - & - & - & 2 & ls \\
\hline \multicolumn{12}{|l|}{ Balanitaceae } \\
\hline Balanites aegyptiaca & + & - & - & - & - & - & - & - & - & 1 & ls \\
\hline \multicolumn{12}{|l|}{ Bombacaceae } \\
\hline Bombax costatum & + & + & - & - & - & - & - & - & - & 2 & ls \\
\hline \multicolumn{12}{|l|}{ Burseraceae } \\
\hline Boswellia dalzielii & - & + & - & - & - & - & - & + & - & 2 & ls \\
\hline Commiphora africana & - & - & - & - & - & - & - & - & - & & \\
\hline Commiphora kerstingii & - & - & - & - & - & - & - & - & - & & \\
\hline \multicolumn{12}{|l|}{ Euphorbiaceae } \\
\hline Bridelia scleroneura & - & + & - & - & - & - & - & - & - & 1 & ls \\
\hline Euphorbia sudanica & - & - & - & - & - & - & - & - & - & & \\
\hline Grewia bicolor & - & - & - & - & - & - & - & + & - & 1 & ls \\
\hline \multicolumn{12}{|l|}{ Asclepiadaceae } \\
\hline Calotropis procera & + & - & - & - & - & - & - & - & - & 1 & ls \\
\hline \multicolumn{12}{|l|}{ Rutaceae } \\
\hline Citrus limon & + & - & - & - & - & - & - & - & - & 1 & ls \\
\hline Citrus grandis & - & - & - & - & - & - & - & - & - & & \\
\hline \multicolumn{12}{|l|}{ Capparaceae } \\
\hline Crateva adansonii & - & - & - & - & - & - & - & - & - & & \\
\hline
\end{tabular}


Diospyros mespiliformis

$+$

$-$

\section{Rubiaceae}

Feretia apodanthera

Mitragyna inermis

Gardenia aqualla

\section{Moraceae}

Ficus asperifolia

Ficus glumosa

Ficus sycomorus

Ficus thonningii

-
-
-

\section{Celastraceae}

Maytenus senegalensis

\section{Moringaceae}

Moringa oleifera

-

(20)

$+2$

\section{Caesalpiniaceae}

Piliostigma reticulatum

Piliostigma thonningii

Senna siamea

Senna singueana

Tamarindus indica

Delonix regia

Myrtaceae

Psidium guajava

$\begin{array}{cc}- & + \\ + & + \\ + & - \\ + & + \\ + & + \\ + & - \\ - & -\end{array}$

$-$

- -


Eucalyptus camadulensis

\section{Fabaceae}

Pterocarpus erinaceus

Pterocarpus lucens

Dalbergia melanoxylon

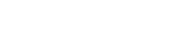

\section{Sterculiaceae}

Sterculia setigera

\section{Bignoniaceae}

Stereospermum kunthianum

\section{Loganiaceae}

Strychnos spinosa

\begin{tabular}{|c|c|c|c|c|c|c|c|c|c|c|c|}
\hline \multicolumn{12}{|l|}{ Sapotaceae } \\
\hline Vitellaria paradoxa & + & - & - & - & - & - & - & - & - & 1 & ls \\
\hline \multicolumn{12}{|l|}{ Verbenaceae } \\
\hline Vitex doniana & + & + & + & - & - & - & - & - & - & 3 & $\mathrm{~s}$ \\
\hline \multicolumn{12}{|l|}{ Olacaceae } \\
\hline Ximenia americana & - & - & - & - & - & - & - & - & - & & \\
\hline \multicolumn{12}{|l|}{ Rhamnaceae } \\
\hline Ziziphus mauritiana & + & + & + & - & - & - & - & - & - & 3 & $\mathrm{~s}$ \\
\hline PSp (\%) & $81.39^{*}$ & $72.09^{*}$ & $30.23^{*}$ & $4.65 * *$ & $2.32 * * *$ & $2.32 * * *$ & $2.32 * * *$ & $4.65 * *$ & $4.65 * *$ & & \\
\hline
\end{tabular}

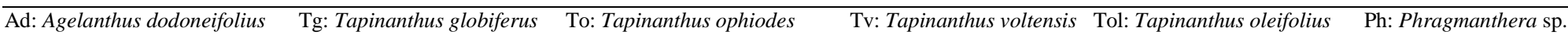

Tsp1: Tapinanthus sp1. Tsp2: Tapinanthus sp2. Tps3: Tapinanthus sp3 PSe: Parasitic sensitivity (1s: little sensitive host; s: sensitive host; hs: high sensitive host;

PSp: Parasitic specificity (*: weak specificity; **: average specificity; ***: high specificity ; NP: number of parasites $\quad+:$ presence $\quad-:$ absence 


\section{DISCUSSION}

\section{Tree diversity and floristic composition of potential host families}

The two divisions of the Diamare plain's ecoregion showed different values of Shannon's index. The Diamare division had moderate value of Shannon's diversity index $\left(\mathrm{H}^{\prime}=3.44\right.$ bits $)$ and weak in the Mayo-Kani division $\left(\mathrm{H}^{\prime}=2.91\right.$ bits) (Table 1). In Mayokani division, most of the individuals were concentrated on a species, Azadirachta indica which is largely extended in that zone. Kent and Cooker (1992) stated that woody communities considered rich are characterized by a Shannon diversity value of about 3.5 bits or higher. The moderate diversity in Diamare division seems to be derived from moderate anthropogenic activities at that level. Such value in savannah indicates a relative stability for the experimental year. The two divisions have shown low evenness index values $(\mathrm{EQ} \leq$ 0.6). Dajoz (1982) cit. Souare (2015) reported that ecosystems that are in a transitional state or that are subject to permanent disturbances have low evenness index value.

In terms of family index value (FIV) of potential host species, Mimosaceae was the most important family throughout the Diamare plain (Table 2). It was followed by Meliaceae, Combretaceae, Anacardiaceae and Balanitaceae. The importance of these potential host families in the study site is due to the fact that drought in the Sahel has allowed natural selection of the most robust species like in these families. They are resistant to the lack and insufficient rains but also to high temperatures. These families are the most common and highly represented in tropical countries, particularly in African savannahs and more typical in sudano-sahelian zones. Similar results were found by Bognounou et al. (2009) and Froumsia et al. (2012), respectively in the sahelian zones of Burkina-Faso and Kalfou forest reserve in the sahelian zone of Cameroon.

\section{Taxonomic diversity of Loranthaceae in Diamare plain}

The Diamare plain recorded nine (09) species of Loranthaceae, distributed within three (03) genera, namely Agelanthus Van Tiegh., Tapinanthus Blume and Phragmanthera Van Tiegh. (Table 3). This taxonomic diversity of three genera and nine species is higher than the three genera and five species obtained in Mali (Boudet and Lebrun, 1986) and to three genera and six species obtained in Burkina-Faso (Boussim, 2002). However, this diversity is significantly lower than the six (06) genera and nineteen (19) species censused in Ivory Coast (Aké-Assi, 1984), the seven (07) genera and twenty six (26) species inventoried in the equatorial zone of Cameroon (Balle, 1982) and the four (04) genera and ten (10) species found in guinean and sudano-guinean zones in Benin (Houenon et al., 2012). The differences obtained would be due to the extent of the study area. Dibong et al. (2008) obtained four (04) genera and eight (08) species in the only Coastal Littoral Region of Cameroon. In fact, taxonomic diversity of Loranthaceae, in terms of genus and species, decreases with the aridity of the zones.

\section{Specificity of the parasitic plants and sensitivity of the hosts}

The 43 host plants censused belong to 20 various botanical families. These results corroborate those of Wiens (1998) and Houenon et al. (2012) who stated that Lorantahaceae species are polyphagous, and therefore parasitize different botanical families without any phylogenetic link. Before that, Boussim (1991) made the same observations on the polyphagous character of the Tapinanthus genus in Burkina-Faso. The same author pointed out the phenomenon of epiparatism or interparasitism of Loranathacea, and it was the case of Tapinanthus globiferus which parasitized Agelanthus dodoneifolius. This case of parasitism was not found in study area, but the two species were very often in association on the same hosts and recorded high significant value of parasitic specificity (PSp > 9\%).

The parasitic sensitivity of the host species vary from a species to another. The most sensitive species (with 5 to 6 parasitic plants) were found among the native species, 
namely Acacia senegal and Anogeissus leiocarpus. A similar study carried out by Houenon et al. (2012) in guinean and sudanoguinean area in Benin pointed out four (04) high parasitic sensitive species, namely Senna siamea, Acacia auriculiformis, Citrus sinensis and Tectona grandis. These differences should be due to extent of the study zone. A total of 34 potential host species censused were found non sensitive, among which are Mangifera indica and Delonix regia. Dibong et al. (2008) in the Littoral region of Cameroon stated that these species are resistant to parasitic plants. However, a survey carried out by Amon et al. (2015) in southern region of Comoé in IvoryCoast found out that these two species were parasitized. These results make us think that to date, there are certainly no resistant species to hemiparasites, but rather species not yet discovered not parasitized by Loranthaceae species.

\section{Conclusion}

The study aimed at contributing to the knowledge of Loranthaceae diversity and their potential hosts in the Sudano-sahelian zone of Cameroon in a view to fighting against degradation of resource plants. Diamare plain situated in this zone harbors nine species of Loranthaceae, distributed within three (03) genera: Agelanthus Van Tiegh., Phragmanthera Van Tiegh. and Tapinanthus Blume. They parasitize fourty three (43) host species of 20 botanical families amongst which Combretaceae and Mimosaceae were the most infested families, with $20.93 \%$ and $16.27 \%$ respectively. Anogeissus leiocarpus and Acacia senegal were grouped in class III (they hosted 5 to 6 parasites), meaning they were high parasitic sensitive in the study zone. Agelanthus dodoneifolius (PSp $=81.39 \%), T$. globiferus $(\mathrm{PSp}=72.09 \%)$ and $T$. ophiodes $(\mathrm{PSp}=30.23 \%)$ performed a weak parasitic specificity. The high parasitic specificity was recorded by Tapinanthus voltensis, Phragmanthera sp. and Tapinanthus sp1. (PSp $=2.32 \%$ ). There was no significant difference between parasitic sensitivity of host species and parasitic specificity of the Loranthaceae $(\mathrm{t}$ test, $\mathrm{p}=0.702)$. One evident outcome from our analysis is that Loranthaceae are polyphagous and parasitize all species in various ecoregions including fragile ecological zones and plantations. An effort should be required for a better control of the development of the species in the study area.

\section{COMPETING INTERESTS}

The authors declare that they have no competing interest.

\section{AUTHORS' CONTRIBUTIONS}

Souare Konsala and Munting Tii Divine carried out the study and developed the manuscript. The other authors read and made comments that improved the manuscript.

\section{AKNOWLEDGEMENTS}

The authors thank the International Foundation for Science (IFS), Stockholm, Sweden, for the support of this research given to Souare Konsala through a grant $\left(\mathrm{N}^{\circ} \mathrm{D} / 4979\right.$ 2). The materials provided by the Foundation permitted to perform this study. We are also grateful to the local communities for their participation.

\section{REFERENCES}

Aké-Assi L. 1984. Flore de la Côte d'Ivoire : Etude Descriptive et biogéographique avec quelques notes Ethnobotaniques. Flore des Angiospermes : Liste commentée des espèces recensées (Lentibulariaceae à Zygophylaceae). Thèse de Doctorat ès Sciences Naturelles, Faculté des Sciences de l'Université d'Abidjan. (Tom Ic), 394-721.

Amon ADE. 2006. Les plantes vasculaires parasites de la famille des Loranthaceae rencontrées dans le Département de Grand-Bassam, au Sud de la Côte d'Ivoire. Mémoire de D.E.A. de Botanique, Université Cocody, U.F.R. Biosciences. Abidjan, Côte d'Ivoire. 57 p. Amon ADE, Soro D, Traoré D. 2015. Evaluation de l'infestation des Loranthacées sur les ligneux des agroécosystèmes de la région du SudComoé (Côte d'Ivoire). International Journal of Biological and Chemical 
Sciences, 9(4): 1822-1834. DOI: http://dx.doi.org/10.4314/ijbcs.v9i4.8.

Azo'o JRN, Tchatat M, Mony R, Dibong SD. 2013. Parasitisme et ethnobotanique des Loranthaceae à Lokomo (Est-Cameroun). Journal of Animal and Plant Sciences, 19(2): 2923-2932.

Balle S. 1982. Loranthacées. In Flore $d u$ Cameroun (Vol. 23), Satabié B, Leroy JF (Eds). Délégation Générale à la Recherche Scientifique et Technique: Yaoundé, Cameroun ; 82 p.

Bognounou F, Thiombiano A, Savadogo P, Boussim JI, Odén PC, Guinko S. 2009. Woody vegetation structure and composition at four sites along latitudinal gradient in Western Burkina Faso. Bois et Forêt des Tropiques, 300: 29-44. DOI: 10.19182/bft2009.300.a20412.

Boudet G, Lebrun JP, Demange R. 1986. Catalogue des Plantes Vasculaires du Mali. Maisons-Alfort, CIRAD-IEMVT. $480 \mathrm{p}$.

Boussim IJ. 1991. Contribution à l'étude des Tapinanthus parasites du karité au Burkina-Faso. Thèse à de $3 \mathrm{e}$ cycle à l'Université de Ougadougou, BurkinaFaso, $130 \mathrm{p}$.

Boussim IJ, Sallé G, Guinko S. 1993. Tapinanthus parasite du karité au Burkina-Faso $1^{\text {ère }}$ partie : Identification et distribution. Bois et Forêt des Tropiques, 238: 45-52. DOI : https://doi.org/10.19182/bft1993.238.a19 774.

Boussim IJ. 2002. Les phanérogames parasites du Burkina Faso : inventaire, taxonomie, écologie et quelques aspects de leur biologie. Cas particulier des Loranthacées parasites du karité. Thèse de doctorat d'état ès Sciences Naturelles. Université de Ouagadougou, Ouagadougou. 285 p.

Dibong SD, Din N, Priso RJ, Taffouo VD, Fankem H, Salle G, Amougou A. 2008. Parasitism of host trees by the Loranthaceae in the region of Douala Cameroon. African journal of Environmental Science and Technology, 2(11): 371 -378.
Dibong SD, Mony R, Azo'o JRN, Din N, Boussim IJ, Amougou A. 2012. Myrmecofauna fruit trees infected by Loranthaceae orchards Lokomo (East Cameroon). International Journal of Plant Research, 2(1): 59-63. DOI:10.5923/j.plant.20120201.09.

Djibrilla M. 2016. Etude de la vulnérabilité de la biodiversité végétale ligneuse dans la zone soudano-sahélienne du Cameroun: cas du Département du Mayo-Kani (Canton de Lara). Mémoire de Master en Biologie des Organismes Végétaux, Université de Ngaoundéré, $80 \mathrm{p}$.

FAO 2011. Les forêts au service de la nutrition et de la sécurité alimentaire. Etude FAO, Rome. 10 p.

Fotsing E. 2009. Small Savannah: Un système d'information pour l'analyse intégrée des changements d'utilisation de l'espace à l'Extrême-Nord, Cameroun. Thèse de Doctorat/ Ph.D, Université de Wageningen, Pays-Bas. 373 p.

Froumsia M, Zapfack L, Mapongmetsem PM, Nkongmeneck BA. 2012. Woody species, composition, structure and diversity of vegetation of Kalfou Forest reserve, Cameroon. Journal of Ecology and the Natural Environment, 4(13): 333-343. DOI: $10.5897 /$ JENE12.047

Grangé D, Libart L. 1992. Traitements Statistiques des Enquêtes. Eds Dunod; $254 \mathrm{p}$.

Houenon JG, Yedomonhan H, Adomou AC, Tossou MG, Akoegninou A. 2012. Le Loranthacées des zones guinéenne et soudano-guinéeene au Bénin et leurs hôtes. International Journal of Biological and Chemical Sciences, 6(4) : 1669-1686. DOI: http://dx.doi.org/10.4314/ijbcs.v6i4.24.

Hoffmann G. 1994. Contribution à l'étude des phanérogames parasites du Burkina Faso et du Mali. Quelques aspects de leur Ecologie, Biologie et Techniques de lutte. Thèse de Doctorat en Sciences de l'Université de Droit, d'Economie et des Sciences d'Aix-Marseille. 177 p.

IPCC. 2007. Groupe de travail I du GIEC: Quatrième Rapport d'évaluation, Bilan 
2007 des changements climatiques les bases scientifiques physiques, Résumé à l'intention des décideurs, $25 \mathrm{p}$.

Kent M, Coker P. 1992. Vegetation Description and Analysis: A Practical Approach. John Wiley and Sons : New York; $363 \mathrm{p}$.

Koffi AA. 2014. Evaluation de l'incidence des Loranthaceae sur la productivité de Hevea brasiliensis (Kunth) Mull.Arg. à Anguédédou (Sud de la Côte d'Ivoire). Mémoire de DEA de Botanique, Université de Cocody, Abidjan. 52 p.

Magurran AE. 2004. Measuring Biological Diversity. Blackwell Publishing: Oxford, UK; p. 256.

MINADT. 2010. Enquête agricole au Cameroun. Manuel d'instruction aux agents recenseurs. $45 \mathrm{p}$.

Mori SA, Boom BM, Carvalino AM, Dos Santos TS. 1983. The ecological importance of Myrtaceae in an eastern Brazilian wet forest. Biotropica, 15: 6870.

Polhill R, Wiens DW. 1998. Mistletoes of Africa. Eds ISBN: Kew ; 370 p.
Sallé G, Tuquet C., Raynal-Roques A. 1998. Biologie des phanérogames parasites. $C$. R. Soc. Biol., 192: 36 p.

Soro D, N'da-Adopo A, Da KP, Traoré D. 2006. Lutte contre les parasites chez le karité. Agronomie Africaine, 16(3): 2128.

Soro D, Ouattarra D, Da KP, Traoré D. 2010. Efficacité de l'émondage contre les Loranthaceae ou Guis du Karité : cas du parc naturel à karités de Tengrela, dans le Nord de la Côte d'Ivoire. Annales de Botanique Afrique de l'Ouest, 3: 87-95.

Souare K. 2015. Gestion intégrée des espèces ressources clés des produits forestiers non-ligneux végétaux au Cameroun : cas de la périphérie du parc national du Mbam et Djerem. Thèse de Doctorat/PhD, Université de Yaoundé 1. $154 \mathrm{p}$.

Wafo G. 2008. Les aires protegées de l'Extrême-Nord Cameroun entre politique de conservation et pratiques locales, Thèse Doctorat en GéographieAménagement-Environnement, Université d'Orléans. 325 p. 